\title{
Rethinking Development Models and Irrigation Projects in Nepal
}

\author{
Floriane Clement, Govinda Banset and Luna Bharati
}

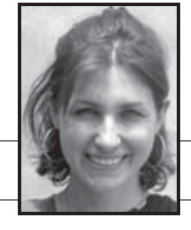

Floriane Clement

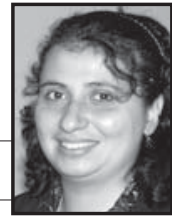

Luna Bharati

Abstract: Despite decades of investment and institutional refinement, externally funded irrigation programs still exhibit low success rates and more particularly in countries facing institutional and political challenges. This paper aims at bringing fresh insights on the reasons for such shortcomings with the particular case study of a donor-sponsored program recently implemented in the Mid and Far Western Regions of Nepal.

Findings indicate that the political situation and institutional system in Nepal have substantially affected the outcomes of the agricultural water management (AWM) interventions conducted by the program. Yet, beyond the influence of these contextual factors, two other (less acknowledged) mechanisms have contributed to create a gap between project objectives and outcomes: a) concepts commonly found in project documents and development discourses such as participation or empowerment are kept vague and ambiguous and lack an explicit recognition of power distribution; and b) the organizational system of many funding agencies tends to create incentives for project staff to show outcomes rather than to make impacts.

These findings suggest that refining current models of AWM interventions is not sufficient to improve their achievements. A more radical shift is needed. A few avenues for change include to: 1) pay a greater attention to the meaning and operationalisation of common development concepts (e.g., rights based approach, empowerment or participation); 2) consider the way interventions affect power distribution among stakeholders, including communities; and 3) modify the organizational system of the funding agency to increase its downward accountability to targeted beneficiaries. To sum-up, we need to rethink development as a means of empowering governments and citizens rather than as a way to provide assistance.

Key words: Development, agricultural water management, Western Region, institutions, discourses, Nepal

\section{Introduction}

$\mathrm{H}$ ow to improve aid delivery in challenging contexts, and particularly in countries qualified as 'fragile states', has been in recent years the focus of a burgeoning literature from the development sector (e.g., François and Sud 2006; Carvalho 2006; ODI 2011; DFID 2005). Because development projects have often had mixed results in these countries, multilateral and bilateral funding agencies have been exploring potential avenues to increase the outcomes of their interventions under these challenging contexts. This is all the more relevant for agricultural water management (AWM) interventions which target complex social-ecological systems (Cifdaloz, Regmi et al 2010; Ostrom, Lam et al 2011). Complexity means in this paper 'a situation where an increasing number of independent variables are interacting in interdependent and unpredictable ways' (Sanders and McCabe 2003, 8).

AWM systems refer to all systems of water use in agriculture, from small to large scale, including irrigation, water harvesting and water conservation. Their complexity stems from several factors. First, water is a highly variable resource with a non-linear and therefore relatively unpredictable behaviour. Second, water systems are multiscalar and physically interconnected in ways which are still often poorly understood. Third, water is a common-pool resource which often requires collective rules to ensure fair access and sustainable management. Lastly, water is a spiritual, religious and social resource, management of which is subject to a myriad of local cultural norms and values. As a result, a huge diversity of customary water management systems have co-existed, governed by local and dynamic institutional arrangements to share, distribute water in a way that is socially acceptable by all water users in the community.
AWM systems are also complex because characterised by a high diversity of social constructs; i.e., perceptions and ways of representing the reality. For instance, different individuals or groups of individuals; e.g., men, women, landless and landlords, farmers and government officials, development practitioners and scientists, might have different perceptions on what would be the desirable objectives of AWM interventions. Research and development projects have largely focused on increasing irrigation efficiency and agricultural productivity, whereas farmers might have other objectives; e.g., for women, meeting domestic uses with the canal irrigation system (Zwarteveen 1998). As a result, many irrigation systems have failed to meet the needs of local water users, and particularly of the most disadvantaged groups (Vincent 1994; Mollinga and Bolding 2004; Turner 1994), and progressively dropped out of donors' agenda (Lankford 2009).

When AWM interventions take place in 'challenging contexts' or 'fragile states', donors and implementing government agencies and NGOs have to cope with yet another layer of complexity in settings dominated by nonlinear institutional, social and political change. This paper explores some of the key mechanisms that create gaps between project intentions, practices and outcomes in the field in complex context. It draws from the case study of AWM interventions recently implemented in the Mid and Far Western Regions of Nepal through an externallyfunded project.

Following a brief presentation of the context and methodology, the paper presents key findings on 1) which factors are perceived to be challenging, according to different groups of actors and notably funding in implementing agencies involved in AWM projects in 
Nepal; 2) how these challenges have created gaps between AWM projects' objectives and outcomes; and 3) why the current way of correcting AWM project shortcomings, that is creating 'new models', has repeatedly failed. Finally, the paper concludes with suggestions regarding possible avenues to move forward and overcome past project failures.

\section{Methodology}

This study was implemented within a larger research project, called 'Improving Sustainability of Impacts of AWM Interventions in Challenging Contexts', conducted by the International Water Management Institute (IWMI) for the International Fund for Agricultural Development (IFAD) in five countries: Burkina Faso, Ethiopia, Ghana, Nepal and Sri Lanka. The research aimed at assessing the impact of challenging contexts on IFAD AWM interventions.

In Nepal, the research focused on the IFADfunded project called the Western Upland

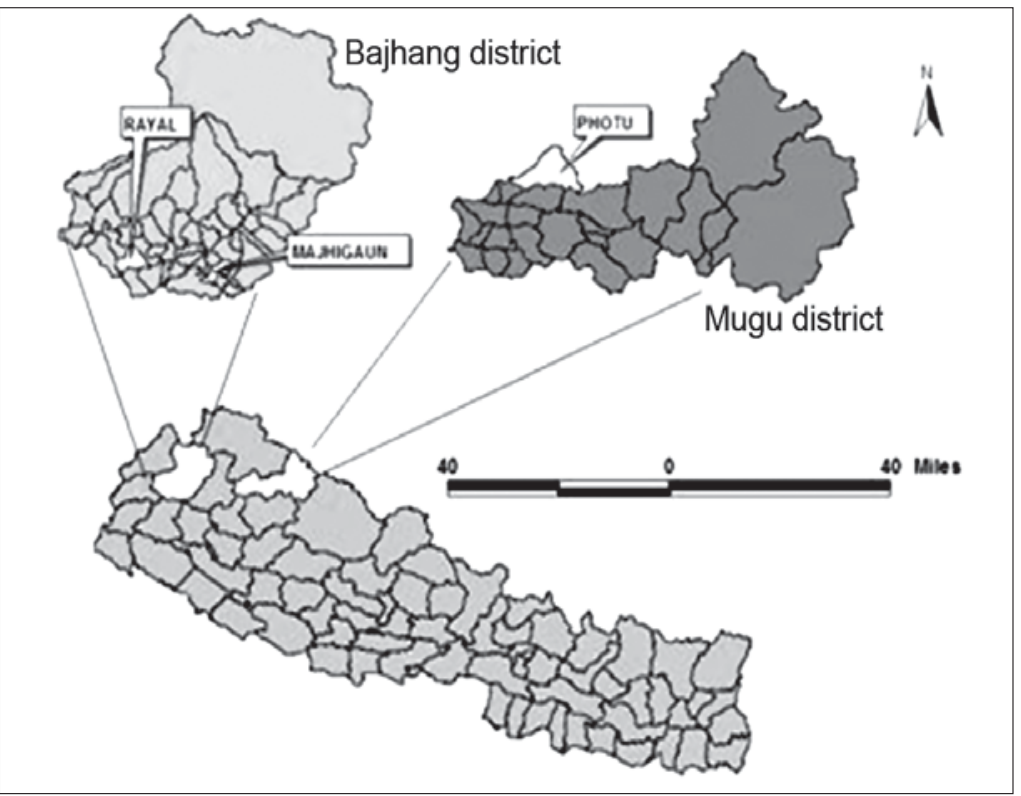
Poverty Alleviation Program (WUPAP), implemented through a project coordination unit under the Ministry of Local Development (MLD) in 11 districts of the MidWestern and Far-Western regions. WUPAP is an 11-year project, implemented since 2003 conducting a wide range of activities under five components, namely:

1) infrastructure development,

2) leasehold forestry and non-timber forest products,

3) crop and livestock production,

4) micro-finance and marketing, and

5) institutional support.

This study focused on the AWM interventions under the first component but however also considered linkages with the other components of the program.

The characterisation of the local context and challenges was based on a preliminary field visit led by the research team and two stages of 10-day and 20-day fieldwork periods in five case study sites led by an experienced Nepali consultant. Four sites were located in two VDCs of Bajhang District in the Far-Western region and one site in Mugu District in the Mid-Western region (Figure 1). Both districts meet many of the criteria of a challenging context: low accessibility with poor road network, health, education and communication infrastructures, weak governance, low food security and life expectancy.

Several AWM interventions had been implemented under the WUPAP project in these sites (Table 1). Fieldwork consisted of semi-structured interviews and focus group discussions with villagers from different gender, age, caste and class groups. It was complemented by interviews with WUPAP project staff and local district government officials; e.g., the Local Development Officer and officials from the District Agricultural Development Offices, District Forest Offices and the Irrigation Development Sub-Division Office (only in Bajhang District).

The characterisation of the national context and its challenges was done through a literature review and a series of interviews conducted with around 20 key informants,

including multilateral and bilateral donors, government officials, NGOs, scientists and consultants, either involved in AWM programs design, implementation or with a renowned experience and knowledge on AWM in Nepal. The interviews explored the perception of challenges among respondents and how they had addressed these challenges in their program.

\begin{tabular}{|l|l|l|c|}
\hline \multicolumn{1}{|c|}{ Village } & District & \multicolumn{1}{c|}{$\begin{array}{c}\text { VDC- Ward } \\
\text { number }\end{array}$} & $\begin{array}{c}\text { Number of } \\
\text { households }\end{array}$ \\
\hline Rayal & Bajhang & Rayal-1 & 183 \\
\hline Chaudam & Bajhang & Rayal-2 & 103 \\
\hline Pothada & Bajhang & Rayal-2 & 42 \\
\hline Majhigaun & Bajhang & Majhigaun-6 & 145 \\
\hline Gilbili & Mugu & Photu-2 & 14 \\
\hline
\end{tabular}

Table 1. Settlements Selected as Case Study Sites (Basnet 2011).

\section{Findings \\ Perception of challenges}

Multilateral and bilateral funding agencies have commonly used the term 'fragile state' (and previously 'Low Income Country Under Stress') to name countries where the context is found challenging for providing assistance. The definition of 'fragile state' varies among donors but all refer to either: 1) a lack of capacity or will of the government to ensure development of its country; e.g., "where the government cannot or will not deliver core functions to the majority of its people, including the poor' (DFID 2005:7); or 2) countries which are 'characterized by weak policies, institutions, and governance' (Carvalho 2006, p.3).

For this study, informants were asked about the main challenges they had faced for their AWM/rural development program. Their answers were classified into different categories, according to the nature of the challenge (Figure 2).

Findings indicate that challenges are primarily perceived as political and institutional (Figure 2). No 


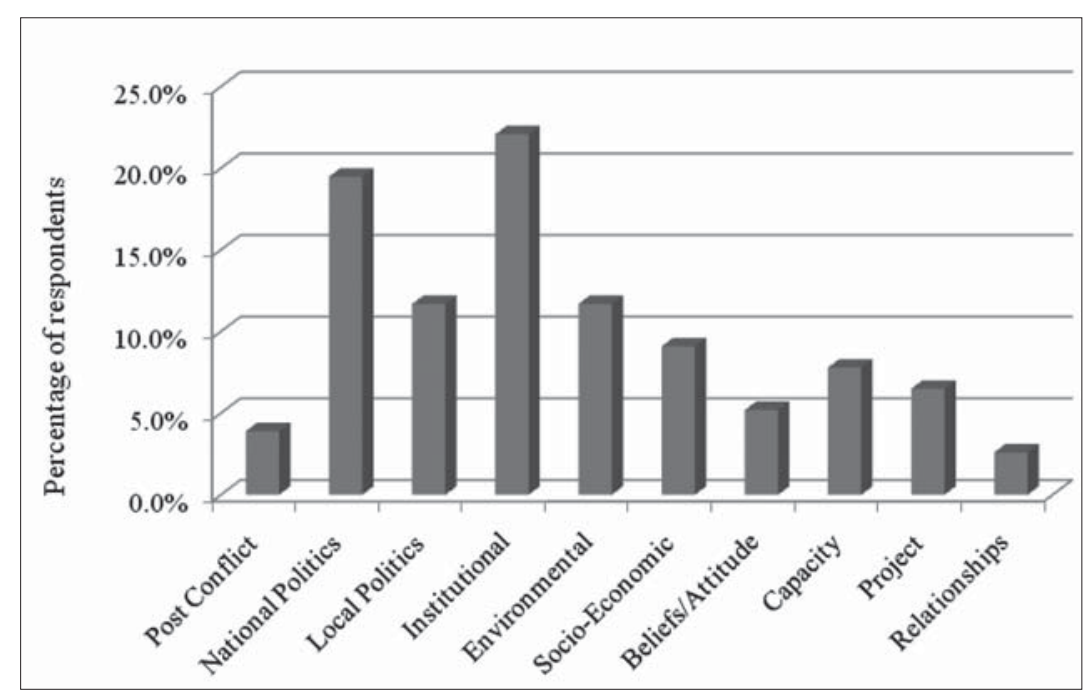

Figure 2. Categories of Challenges Perceived by Respondents (Author's Interviews).

$80 \%$ of the facilities constructed in Phase II are appropriate and adequate'. However, the quality of the irrigation schemes was found to be variable because the latter 'have been designed by insufficiently experienced staff and without adequate technical supervision during construction' (IFAD 2011). In addition, the mission indicates that: 'the focus of the infrastructure activities has been heavily biased towards construction with insufficient attention to appropriate community-led operation and maintenance (O\&M) arrangements' (IFAD 2011).

Results from our fieldwork highlighted similar shortcomings. One out of the five AWM interventions surveyed suffered from technical defects related to poor design (Table 2). Two other ones were not completed because of increase in material

marked difference in perception of the nature of challenge was evidenced among the groups of actors interviewed at the national level; e.g., bilateral donors, multilateral donors, NGOs and government officials. Several common issues were quoted across the groups such as the postconflict situation, a weak/fragile/instable government, the lack of local elected representatives and the politicisation of projects at the district and local levels. The government and politicians were perceived by donors to be the major actors 'responsible' for making the context challenging.

The perception of challenges was found to vary between the national and local levels. For instance, for the district government officials interviewed in Bajhang and Mugu Districts, it was the local politicians and communities' attitude that were making their tasks challenging. They also mentioned 'project dependency syndrome' as a major issue. Not surprisingly, the perception of challenges was found to clearly depend on actors' position.

\section{Project outcomes in the field}

In the second phase of WUPAP (2007-2011), 473 schemes were implemented (over the initial target of 400 schemes), benefiting a reported total of over 29,600 households among which 7,450 households (40\%) benefited from irrigation schemes. According to the latest joint review mission conducted by IFAD at the end of 2011, the 'design, construction and maintenance standards for costs and local conflicts over misuse of funds and water use rights. Furthermore, in all sites, the user groups formed by the project to operate and maintain the canal became dysfunctional after the rehabilitation works were completed (Basnet 2011).

\section{Linking challenges and project outcomes: Two Perspectives}

The next step in the analysis was to explore the potential links between the challenges identified by funding and implementing agencies and results from the field. A guiding question was to assess whether the challenges identified by respondents in Kathmandu had significantly affected the outcomes of AWM interventions in the case of WUPAP and to untangle the mechanisms that linked challenges and outcomes.

\section{The technical-managerial explanation}

All the challenges described by the respondents were observed to significantly contribute to the gaps between project objectives and outcomes in the case of WUPAP. For instance, the lack of elected representatives in the Village Development Committees (VDCs) and District Development Committees (DDCs) has worsened the politicisation of development projects, particularly in Mugu District. Most local NGOs are affiliated to one or the other political party, and each political party naturally

\begin{tabular}{|l|l|l|l|l|l|}
\hline $\begin{array}{l}\text { Irrigation system } \\
\text { District }\end{array}$ & $\begin{array}{l}\text { Rayal/Chaudala } \\
\text { Bajhang }\end{array}$ & $\begin{array}{l}\text { Pothada } \\
\text { Bajhang }\end{array}$ & $\begin{array}{l}\text { Choudam } \\
\text { Bajhang }\end{array}$ & $\begin{array}{l}\text { Majhigaun } \\
\text { Bajhang }\end{array}$ & $\begin{array}{l}\text { Gilibli } \\
\text { Mugu }\end{array}$ \\
\hline $\begin{array}{l}\text { Type of AWM } \\
\text { intervention }\end{array}$ & $\begin{array}{l}\text { Rehabilitation, } \\
\text { cement lining }\end{array}$ & $\begin{array}{l}\text { Rehabilitation, cement } \\
\text { lining }\end{array}$ & $\begin{array}{l}\text { Rehabilitation, } \\
\text { cement lining }\end{array}$ & $\begin{array}{l}\text { New irrigation } \\
\text { system, pipe lining }\end{array}$ & $\begin{array}{l}\text { Rehabilitation, } \\
\text { cement lining }\end{array}$ \\
\hline Major challenge & $\begin{array}{l}\text { Work abandoned } \\
\text { because of an } \\
\text { alleged misuse of } \\
\text { fund }\end{array}$ & $\begin{array}{l}\text { Work abandoned } \\
\text { because of dispute } \\
\text { over water rights and } \\
\text { misuse of funds }\end{array}$ & $\begin{array}{l}\text { Existing landslide } \\
\text { downstream the } \\
\text { rehabilitation work }\end{array}$ & $\begin{array}{l}\text { Work not } \\
\text { completed as } \\
\text { designed because } \\
\text { of a lack of fund. }\end{array}$ & $\begin{array}{l}\text { Regular small } \\
\text { landslides }\end{array}$ \\
\hline $\begin{array}{l}\text { Current status of } \\
\text { intervention }\end{array}$ & $\begin{array}{l}\text { Not completed but } \\
\text { improved sections } \\
\text { function well }\end{array}$ & $\begin{array}{l}\text { Functioning well, small } \\
\text { section damaged by } \\
\text { land slide }\end{array}$ & $\begin{array}{l}\text { Rehab work made } \\
\text { little change }\end{array}$ & $\begin{array}{l}\text { No drainage } \\
\text { system, settlement } \\
\text { gets flooded }\end{array}$ & $\begin{array}{l}\text { Small landslides } \\
\text { damaged the } \\
\text { canal }\end{array}$ \\
\hline $\begin{array}{l}\text { Change in water flow } \\
\text { after the intervention }\end{array}$ & $\begin{array}{l}\text { Significantly } \\
\text { increased }\end{array}$ & Increased & Negligible & Increased & Increased \\
\hline
\end{tabular}

Table 2. Outcomes of WUPAP AWM Interventions in the Five Case Studies (Basnet 2010, 2011). 
champions its NGO for implementing WUPAP. In the absence of a district level elected body, representatives of political parties are battling for their interests in nonending negotiations. In Mugu, the selection process for the NGO to implement WUPAP in 2010-2011 came to a deadlock and the project was put on hold before finally being suspended in this district (field visit, November 2010).

Another common challenge is the delay in taking decisions at the ministry level. That also proved to significantly affect WUPAP implementation and outcomes. Particularly, delays in fund transfers from the Ministry of Finance to the MLD had far-reaching consequences in the field - for example, purchased seeds did not reach farmers on time for the planting season (pers. comm., WUPAP country coordinator, March 2010).

The lack of technical capacity available in the field has also led to defects in the rehabilitated irrigation systems as identified by the latest joint review mission of WUPAP. In the village of Pothada in Bajhang District, the canal rehabilitation brought little improvement because the rehabilitated section was downstream a section damaged earlier by a landslide. In this respect, the natural environment was an additional challenge. Natural disasters, and notably landslides, seriously damaged two of the five irrigation systems surveyed (before and after the intervention), thereby considerably reducing their performance. Another important feature of the biophysical and socio-economic context is the low accessibility of the sites, which adds further constraints on the project implementation, notably the difficulty to recruit and keep qualified staff within the project and district government agencies, transport construction materials and the increase of the daily burden of the social mobilizers in terms of time and effort spent to reach the sites.

Although the impacts of identified challenges are real and substantial, this causal chain of explanation reflects a particular view, which can be labelled as 'technical-managerial'. Most respondents from funding and implementing agencies perceived issues as challenging insofar as they were causing delays in project implementation, increased costs and, as a whole, hindered financial and physical progress. The dominant solution advocated to fix these problems has been to refine the 'project model' by creating 'better' institutions. Institution is understood here as formal or informal rules-in-use, for instance contractor guidelines, rules on the regularity and mode of fund transfer and on the form of community participation. The rationale is that the right model and institutional arrangements will lead to successful projects.

Institutions are indeed key components of projects as they shape actors' interactions and create or transform the set of incentives that influence their decisions. Another important but less acknowledged function of institutions is to modify power distribution among individuals and groups of actors. For instance, under some social settings, the rule to hold community meetings in a public space can deter women's participation because of prevailing gender norms.

The argument developed here is that, in a majority of AWM interventions, institutional design has been geared towards fulfilling technical-managerial objectives (e.g., organising a community meeting) but has not been used as a means to address or challenge existing power distribution among project stakeholders (e.g., giving more decision-making power to the most disadvantaged). The next sub-section offers an alternative perspective on the causal factors that have created gaps between project intentions and outcomes. The argumentation first draws insights from WUPAP case study sites before enlarging to dominant perceptions among donors, government agencies and NGOs interviewed in Kathmandu and to development studies in general.

\section{The power-oriented explanation}

First, re-consider the technical defects previously highlighted in WUPAP. A lack of technical capacity at the district and project levels was evident in terms of design and implementation and irregular check-ups during the construction phase (pers. comm., WUPAP project coordinator, January 2012). The commonly advocated solution in this technical-managerial view would be to increase the technical capacity and checks.

From a power-oriented perspective, a more critical issue is the lack of accountability of the project staff to people in communities. At the time the interventions were implemented, there was hardly any mechanism built in the program for communities to make the chairperson and secretary of the committee (acting as contractor), the local field staff, the WUPAP project coordination unit, or IFAD staff accountable to them. Majhigaun gets regularly flooded because the intervention could not be completed due to an increase in material costs. Subsequent requests of the community to complete the irrigation system were not met because the maximum amount per intervention allowed by the project had been allocated to the village. The community has no means to influence IFAD to complete their irrigation system.

The main accountability mechanisms in place within WUPAP are the occasional evaluations commissioned by IFAD such as mid-term reviews, supervision missions, joint review missions and independent evaluations. Recently, the project started to conduct social audits. This is a positive move towards enhancing project accountability, as long as it is not a mere administrative exercise. After the latest joint review mission highlighted technical defects, a decision was also taken to check all structures and rehabilitate those defunct (IFAD 2011). However, the success of such an operation will depend on the good will of a team of engineers and it is unclear whether communities and individuals will have a voice to ensure that the process responds to their needs.

The lack of downward accountability is not specific to WUPAP. In most development projects, when the intervention fails to deliver products and services to a community, there is no mechanism for the later to sanction the project. In the development sector, there is a common disconnection between those to whom donors are ultimately accountable (tax-payers in the case of the bilateral donors) and the communities and individuals targeted by the project (Gibson, Andersson et al 2005; Oxfam 2011). The latter usually provide inkind contribution through labor and should therefore also be entitled to a stake in the outcomes. Yet most donors perceive in-kind contribution as a way to create 
community ownership of the structures rather than as a motive for increased downward accountability.

Landslides have been a real threat to the sustainability of structures. Yet a power-oriented perspective also highlights that only one source and form of knowledge has been considered: that of engineers. Farmers had warned the project staff of the recurrent landslides, but, as in many so-called 'participatory approaches', their participation was confined to labor contribution and there were limited avenues to integrate their knowledge in the design of the intervention (Basnet 2010).

Yet traditional irrigation systems have shown a high sustainability because the regularity and low cost of their maintenance has provided incentives to farmers to cooperate to repair them over long periods of time (Lam 1998). In the case of externally-led interventions, farmers are either not able to repair cemented structures because of a lack of knowledge or high cost, or they prefer to wait for the next external project to fund the repair - the project dependency syndrome mentioned earlier.

Translating aid into a daily life situation, these two examples could be narrated as follows: you live in a house which your family has maintained for generations. One day, someone knocks at your door and asks if you would like a new roof, a modern and solid one. You accept the offer - free aid, why should you refuse it? The person sends a contractor who asks you to work under his directives. There is nobody to check the contractor' work and since you do not know much about modern roofs, you are not able to control the quality of the structure. A week after the roof is completed, it starts leaking under a small storm - something frequent in this region. You cannot fix it because you do not know how to repair this modern roof. The contractor does not care. You call the person who first came to your house. The later apologises, but they cannot send back the contractor to repair your roof, because they already provided aid to you and now they have to aid other people as well...

This is not to say that aid is irrelevant. But dominant forms of aid have often followed the same patterns and been criticised for similar shortcomings: lack of downward accountability, lack of sustainability, neglect of local knowledge, etc. Development studies have explored why these shortcomings have sustained and this study has built on some of the major contributions from this body of knowledge (Cornwall and Eade 2010; Li 2007; Mosse 2005) to analyse AWM interventions in the specific context of Nepal. We discuss in the next section two major themes that have recurrently misguided development interventions: the use of simplistic narratives in development discourses and the particular set of incentives that drive institutional change in aid interventions.

\section{Two Entry Points to Move Forward Discourses and practices}

A discourse is understood as a 'a specific ensemble of ideas, concepts, and categorizations that is produced, reproduced, and transformed in a particular set of practices and through which meaning is given to physical and social realities' (Hajer 1995). Discourses legitimise policies and institutions and shape beliefs and values. By establishing what is 'true' (Feindt and Oels 2005), what is legitimate, legal and normal, they include/exclude certain groups of actors and views (Peluso 1992). Discourses are therefore a way to both express and exercise power and can be envisioned as the articulation of knowledge and power (Escobar 1996).

For instance, discourses on water productivity herald 'efficiency' as the main goal and, as a result, related interventions have often disregarded issues of equity as notably exemplified by the so-called 'modernization' of irrigation systems in Nepal (Ostrom, Lam et al 2011). Because water productivity discourses depict water as a free flowing resource which needs to be managed rationally and efficiently, most water productivity initiatives have neglected notions of access and distribution of resources, and more broadly the political character of water management (Clement In Press). Note that by 'political', I mean embedded in power relationships (see Mollinga 2008), not 'political' in the sense of party politics.

In development discourses, terms such as 'participation', 'equity', 'inclusiveness' and 'empowerment' are interesting to explore because of their 'buzzword' attributes. A buzzword is typically a concept that is omnipresent in discourses and that carries ambiguous and multiple meanings which make it easily malleable to justify different types of interventions (Cornwall and Brock 2005). To gather a large consensus, buzzwords have been largely dispossessed of their political content (Cornwall and Eade 2010). For instance, 'participation' was initially envisioned as a process of social transformation whereby power inequalities among actors are reduced. For some international agencies it has become an efficient and cost-effective way to reach the poorest (Mayo and Craig 1995). The concept of participation has also often been used as an alibi for transferring responsibilities (without delegating decision-making power). As an NGO staff was commenting: 'in the name of participation, the poor do most of the work for free and are exploited' (Interview International NGO, Kathmandu, March 2011).

The WUPAP implementation was to follow a 'rights based approach', which can be considered as a further step towards empowerment compared to 'participation'. The rights based approach was to 'empower the participants by mobilizing their natural, physical and financial resources to harness external resources and obtain social justice' (MLD - WUPAP Project Coordination Unit 2007). This statement from WUPAP project document contains strong and political words such as 'empower' and 'obtain social justice'. However, as for many development projects Batliwala (2007), the limited downward accountability of the local NGO contracted to implemented the project in Mugu District and their underpaid staff have few incentives to deliver on such objectives (Basnet 2011).

When asked about how participation was operationalized, many of the funding and development agencies interviewed in Kathmandu described it in an apolitical manner. Participation was either described as the contribution of the community to the construction works; e.g., 'we ask for a major involvement of the community: 50\% including 40\% work and 10\% cash' (interview international NGO, Kathmandu, March 2011), as a presence at project meetings, or as the choice to select the project activities to be implemented in their village.

Whereas these are all forms of participation, these types of interaction give a limited space to individuals and 
communities to express their needs and build their capacity to improve their livelihood. Participation in meetings is often elite- and male-dominated - even if all are present, not everybody speaks and, even if everybody speaks, not everybody's voice has the same weight. The inherent rationale and, at the same time, challenge for participatory approaches is to overcome existing power relationships within the community and between the community and outsiders (project staff, government officials, contractors, etc) (Emmett 2000). If not addressed, the risk for any external intervention is to reproduce or even reinforce existing power inequalities and benefit only those who already have networks, assets and knowledge (Mosse 2005). The assumption that the marginalised will benefit through the trickle-down effect has been challenged by a wealth of studies for several decades (Bardhan 1986; Arndt 1983; Gaiha 1995).

A way to address this issue is to adopt a pro-active and affirmative approach to challenge existing power distribution linked with gender, caste, class and ethnicity. Targeting the most disadvantaged groups, building their capacity and giving them a voice in decision-making processes could help to overcome some of the existing inequities. It obviously requires more human and time resources than a conventional 'participatory approach', as it might include for instance, visiting women or agricultural laborers individually at their home or overcoming resistance from the elite group (Mosse 2005).

It is however a possible choice, which has been made by some of the NGOs and donors interviewed, as exemplified in the following quotes: 'We have made a strong stand to pay equally men and women. It took time to implement, and it was hard, we had to repeat 100 times, but now women are proud to get the same salary as men' (interview bilateral donor, Kathmandu, March 2011) or 'We don't focus much on figures. (...) We look at more qualitative aspects. We have different tools. One is (...) like a community forum where women participate when they have time (...). They start talking about social issues, and they develop a plan to improve the situation. For instance, we provide basic literacy to help them marketing' (interview bilateral donor, Kathmandu, March 2011). The study could not collect evidence to assess whether these interventions have actually resulted in women's empowerment (e.g., were the women able to keep their salaries or did their husband claim it, what kind of plan did women develop), but such statements are at least indicative of a pro-active approach directed towards empowerment of the most disadvantaged.

Similarly, some of the respondents were asked how local people were empowered within their program. Most respondents referred to processes which actually delegate responsibilities but little power; e.g., 'We constitute water user associations and, at the end, the project is handed to them, after, they have to run the project' (interview government official, Kathmandu, March 2011). Some described empowerment as a process depending on the community's own will: 'If people have interest, they will be empowered' (interview government official, Kathmandu, March 2011). At best, empowering was described as letting the community decide on the project activity. These statements reflect a discourse that envisions the community as 'recipients' and 'beneficiaries' but not as playing a leading role in their development. Individuals participate but within a specific framework defined by the implementing/funding agency.

Project documents also confirmed that dominant discourses on participation, empowerment and rights based approach are largely apolitical and ambiguous about how these concepts will be effectively operationalized in the field. Such discourses leave sufficient freedom for multiple actors to interpret and model those concepts according to their needs, interests, values and capacity.

\section{Official and organizational objectives}

This discursive ambiguity, which allows multiple interpretations of participation or empowerment, collides with a specific form of institutional set-up that characterizes many major development projects. In the aid sector, strong incentives steer projects away from the official stated objectives (poverty reduction, food security, etc.) to achieve organisational objectives (spend money, show outcomes to the board, etc.) (Mosse 2005).

As processes are focusing on achieving organisational objectives, key principles of the project, e.g., inclusion and social equity, become either secondary or assumed. For instance, monitoring tangible physical outcomes are preferred to monitoring social impacts which are more difficult to assess and it is assumed that the former will lead to the later. As a result, many projects suffer from under-skilled and understaffed human resources to ensure genuine community participation. Project staff also often lack incentives to follow the original ideals of empowerment, social justice, which clearly require different types of efforts than the achievement of organisational objectives.

In the case of WUPAP, incentives towards achieving organizational objectives were evidenced in a variety of ways. For instance, a social mobilizer was acknowledging that the farmers she visited to create the community organization were the most 'progressive' farmers; i.e., the village elite because they were usually more easily convinced to take part in these initiatives. Even if all households become members of the organization, the influence they have in decision-making is likely to be influenced by existing power distribution, unless an affirmative approach is adopted by the project. However, social mobilizers are not evaluated in terms of ensuring that the poor do get a voice but in terms of the number of community organizations and user groups formed and number of meetings held. Again, the NGO staff have few incentives to devote more efforts than what they need to get a meagre salary.

In addition, WUPAP monitoring and evaluation system is geared towards physical and financial progress and outcomes and there is no systematic evaluation on whether interventions have actually followed a rights based approach as per the project documents. This is the case for many development projects' evaluation systems. Those concentrate on results and outcomes, and more recently to some extent on impacts, but have largely neglected processes and the respect of the key principles they advocate.

\section{Conclusion}

This paper examined some of the difficulties in implementing agricultural water management (AWM) 
interventions in challenging contexts, and particularly in Nepal. Based on the case study of WUPAP, a donor-funded project currently implemented in the Mid and Far Western Regions of Nepal, the study explored the gap between project intentions and outcomes in the field. Findings showed that the challenges resulting from the current political situation and institutional system in Nepal have substantially affected project outcomes.

To address such challenges, the predominant way to improve AWM programs and development models has been to design better models by refining institutions. Yet despite decades of aid in Nepal, most respondents interviewed in Kathmandu were critical of the performance and contribution of donors' interventions. The argument developed in this paper is that such shortcomings have sustained because institutions have been considered more as instruments to achieve technical-managerial objectives than as ways to alter power distribution among actors.

Technical-managerial problems such as lack of capacity, delay in decisions and fund transfers are all important issues and need institutional change to be addressed. But the analysis evidenced two other factors that contributed to create a gap between discourses and practice and which are rarely explicitly considered by funding agencies. One is the ambiguous and apolitical character of dominant discourses and the second is the type of incentives created by the organizational system. The analysis defends the need to reconcile the technical-managerial approach with a more power-oriented perspective. The latter argues for 1) transferring more power to local people, and especially disadvantaged groups to influence decisions on project design and implementation, and 2) offering them more opportunities to build their capacity and enhance by themselves their livelihoods.

Pathways to move forward could be first to deconstruct the meanings of key concepts such as participation, empowerment or equity and make their political content more explicit to those who design and implement projects and evaluate their impacts. For instance, Cornwall and Brock (2005) propose to use chains of equivalence that link buzzwords with more radical terms such as justice or solidarity (2005). Second, how these concepts are operationalized on the field requires more attention. This should be clearly defined and once defined, allocated sufficient resources and adequately monitored.

Some bilateral donors and NGOs have already made a step in this direction, for example by integrating local knowledge and customary informal institutions in project design, recognising the diversity of individuals' capabilities and needs within a community, or conducting social audits whereby local people are given a voice. In times when donors strive for increased budget efficiency, it might be difficult to defend such approaches, especially in challenging contexts and fragile states. A first step in such environments would be to set modest and realistic objectives to ensure quality of outcomes and impacts.

Another way forward is to rethink aid in a different way. Alternative forms of aid already include supporting existing government programs, whereby the donors play the role of adviser and expert to guide government staff on identified weaknesses, but where the program ownerships remains with the government. Such an approach, however, is valid only in specific settings, where the government is committed to serving the poor and has relatively wellfunctioning institutions.

A more radical approach for aid, and probably most adapted to challenging environments, would be to give local people more power and control over the means through which they can improve their livelihoods, where the role of the funding agency would be limited to responding and supporting individual and collective initiatives. There is certainly no panacea and any intervention needs to be adapted to the national and local contexts, but to give an example, it could take the form of service centres where advice, loans, and subsidised inputs can be accessible to all on a long-term basis, with a special support for marginalised groups. Such an approach however does not fit with a project mode and requires fundamental changes in the type of incentives that are currently generated by the dominant forms of aid organizational systems; e.g., increasing accountability mechanisms and privileging the quality of processes and impacts over the quantity of outcomes.

To conclude, we need to rethink development as a way to empower government and citizens rather than as a means to provide assistance.

\section{Acknowledgements}

Many thanks to the farmers in Bajhang and Mugu Districts who provided their views for this study. Special acknowledgements to IFAD and WUPAP project staff, Mr. Bashu B. Aryal, IFAD country operations officer in Nepal, Mr. Ramesh Kumar Adhikari, WUPAP project coordinator, Mr. Purusottam and Mr Laxmi, District Program Manager in Bajhang and Jumla Districts, Mrs. Basanti Bhandari, Social Mobilizer in Bajhang District, Mr. Jaya Bahadur Malla, from WUPAP team in Mugu District. This study was conducted within a research project called 'Improving Sustainability of Impacts of Agricultural Water Management Interventions in Challenging Contexts' funded by IFAD.

Thanks to Dr. Doug Merrey, Dr. Katherine Snyder, Dr. Fraser Sugden and Terry Clayton for their insightful comments on a draft version of this paper.

Floriane Clement, PhD, Researcher, International Water Management Institute, IWMI-Hyderabad (India). Dr. Clement has been working at IWMI since 2008. She has an engineering degree from France, a Master degree in Environmental Sciences from Chalmers University, Sweden, and a Doctorate in Geography/ Political Science from Newcastle University, UK. Her major interest and expertise lies in the analysis of the institutional and political factors creating gaps between policy intentions and outcomes in the implementation of natural resource policies and interventions. Initially her research at IWMI focused on the interface between water productivity and poverty in the Ganga Basin, India. Recently she has been investigating the institutional performance of watershed development programmes in Andhra Pradesh, India and how challenging contexts affect donor-driven agricultural water management interventions in Nepal and Sri Lanka. Corresponding address:f.clement@cgiar.org

Govinda Banset, PhD, Freelance Consultant, is an environmental anthropologist and has over 15 years of 
experience working on natural resource management. He has a Master degree in Ecological Agriculture from Wageningen Agricultural University, the Netherlands and a doctorate in Ecological and Environmental Anthropology from the University of Georgia, USA. His key areas of interest and expertise are: mountain environment; development anthropology; social institutions; integrated conservation and development projects; rural water management and policies; project development and management; common pool resource management; general agriculture; climate change; and geographic information science.

Luna Bharati, PhD, has over 15 years of experience in projects related to natural resources and land and water management. She has a Masters in Water Resources and a Doctorate from the Faculty of Agriculture focusing on surface hydrology, erosion and pollutant transport. She has worked in projects in Nepal, USA, Germany, India, Bangladesh, China, Ghana and Burkina Faso. The key areas of her interests and expertise are in: Field investigation and modeling of erosion and nutrient transport and the impacts on water quality (models used: AGNPS, Erosion 3D), Modeling the water balance of a catchment and the influence of climate and land use change using distributed watershed models (e.g.,WaSimETH, SWAT, GeoSFM, WEAP), Developing integrated environmental and economic models for calculating optimal water use and allocation for decision support systems, Calculating environmental flow requirements in the context of basin water allocation strategies. Currently, Dr. Bharati is a Senior Researcher in Hydrology and Water Resources and the Head of the International Water Management Institute (IWMI)-Nepal office.

Corresponding Address: l.bharati@cgiar.org.

\section{References}

Arndt, H. W., 1983, The "Trickle-down" Myth. Economic Development and Cultural Change 32 (1):1-10.

Bardhan, P. K., 1986, Poverty and "Trickle-Down" in Rural India: A Quantitative Analysis. In Agricultural change and rural poverty: Variations on a theme, edited by D. Narain. Oxford: Oxford University Press.

Basnet, G., 2010, Improving Sustainability of Impacts of Agricultural Water Management Interventions in Challenging Contexts. The Case study of IFADsupported project WUPAP, Nepal - Fieldwork Report I. Kathmandu: Consultancy report for the International Water Management Institute (IWMI).

IWMI, 2011, Improving Sustainability of Impacts of Agricultural Water Management Interventions in Challenging Contexts. The Case study of IFADsupported project WUPAP, Nepal - Fieldwork Report II. Kathmandu: Consultancy report for the International Water Management Institute (IWMI).

Carvalho, Soniya, 2006, Engaging with Fragile States, An IEG Review of World Bank Support to Low-Income Countries Under Stress, edited by World Bank. Washington DC: World Bank,.

Cifdaloz, Oguzhan, Ashok Regmi, John M. Anderies, and Armando A. Rodriguez, 2010, Robustness, vulnerability, and adaptive capacity in small-scale social-ecological systems: The Pumpa Irrigation System in Nepal. Ecology and Society 15 (3):39.

Clement, Floriane, In Press, From Water Productivity to Water Security: A paradigm shift?.In 'Water security: Principles, perspectives and practices', edited by B. A. Lankford, K. Bakker, M. Zeitoun and D. Conway. London: Earthscan Publications.

Cornwall, Andrea, and Karen Brock, 2005, What do Buzzwords fo for Development Policy? A critical look at 'participation', 'empowerment' and 'poverty reduction'. Third World Quaterly 26 (7):1043-1060.

Cornwall, Andrea, and Deborah Eade, eds., 2010, Deconstructing Development Discourse. Buzzwords and Fuzzwords. Rugby, UK: Practical Action Publishing in association with Oxfam GB.

Department for International Development, 2005, Why We Need to Work more Effectively in Fragile States. London: Department for International Development.

Emmett, Tony, 2000, Beyond community participation? Alternative routes to civil engagement and development in South Africa. Development Southern Africa 17 (4):501-518.

Escobar, Arturo, 1996, Constructing Nature. Elements for a poststructural political ecology. In Liberation Ecologies: Environment, development and social movements, edited by R. Peet and M. Watts. London: Routledge.

Feindt, Peter H., and Angela Oels, 2005, Does Discourse Matter? Discourse analysis in environmental policy making. Journal of Environmental Policy and Planning 7 (3):161-173.

François, Monika, and Inder Sud, 2006, Promoting Stability and Development in Fragile and Failed States. Development Policy Review 24 (2):141-160.

Gaiha, Raghav, 1995, Does Agricultural Growth Matter in Poverty Alleviation? Development and Change 26 (2):285-304.

Gibson, Clark C., Krister Andersson, Elinor Ostrom, and Sujai Shivakumar, eds, 2005, The Samaritan's Dilemma: The political economy of development aid. Oxford: Oxford University Press.

Hajer, Maarten J., 1995, The Politics of Environmental Discourse: Ecological modernization and the policy process. Oxford, UK: Oxford University Press.

IFAD, 2011, Nepal. Western Uplands Poverty Alleviation Project (WUPAP) Loan: 576-NP Grant: DSF-8010NP. Joint Review Mission: 1st - 19th December, 2011. AideMémoire. Rome: IFAD.

Lam, Wai Fung, 1998, Governing Irrigation Systems in Nepal. Institutions, infrastructure, and collective action. Oakland, CA: ICS Press.

Lankford, Bruce, 2009, Viewpoint - The right irrigation? Policy Directions for Agricultural Water Management in Sub-Saharan Africa Water Alternatives 2 (3):476480 .

Li, Tania Murray, 2007, The Will to Improve. Governmentality, Development and the Practice of Politics. Durham/London: Duke University Press.

Mayo, M., and G. Craig, 1995, Community Participation and Empowerment: The human face of structural adjustment or tools for democratic transformation? In Community Empowerment: A reader in participation and development, edited by G. a. M. Craig, M. . London: 
Zed Books.

Ministry of Local Development - WUPAP Project Coordination Unit, 2007, First Phase of WUPAP (2003/04 - 2006/07). Nepalgunj, Nepal.

Mollinga, Peter P., 2008, Water, Politics and Development: Framing a Political Sociology of Water Resources Management Water Alternatives 1 (1):7-23.

Mollinga, Peter P., and Alex Bolding, eds., 2004, The Politics of Irrigation Reforms. Contested policy formulation and implementation in Asia, Africa and Latin America, Global Environmental Governance series. Aldershot: Ashgate Publishing Ltd.

Mosse, David, 2005, Cultivating Development. An ethnography of aid policy and practice. New Delhi: Vistaar Publications.

Ostrom, Elinor, Wai Fung Lam, Prachanda Pradhan, and Ganesh Shivakoti, 2011, Improving Irrigation in Asia: Sustainable Performance of an Innovative Intervention in Nepal: Edward Elgar.

Overseas Development Institute (ODI), 2011, Getting better results from assistance to fragile states. In Briefing Paper, edited by ODI. London: ODI,.
Oxfam, 2011, The 'Right' Results. Making sure the results agenda remains committed to poverty reduction. In Oxfam Briefing Paper, edited by Oxfam.

Peluso, Nancy, 1992, Rich Forests, Poor People: Resource control and resistance in Java. Berkeley: University of California Press.

Sanders, T. Irene, and Judith A. McCabe, 2003, The Use of Complexity Science: A Survey of Federal Departments and Agencies, Private Foundations, Universities and Independent Education and Research Centers. A report prepared for the U.S. Department of Education. Washington, DC: Washington Center for Complexity and Public Policy.

Turner, Beryl, 1994, Small-scale Irrigation in Developing Countries Land Use Policy 11 (4):251-261.

Vincent, Linden, 1994, Lost Chances and New Futures. Interventions and institutions in small-scale irrigation. Land Use Policy 11 (4):309-322.

Zwarteveen, Margreet Z., 1998, Identifying Gender Aspects of New Irrigation Management Policies. Agriculture and Human Values 15 (4):301-312.
...Continued from Page 22

Luna Bharati, $P h D$, has over 15 years of experience in projects related to natural resources and land and water management. She has a Masters in Water Resources and a Doctorate from the Faculty of Agriculture focusing on surface hydrology, erosion and pollutant transport. She has worked in projects in Nepal, USA, Germany, India, Bangladesh, China, Ghana and Burkina Faso. The key areas of her interests and expertise are in: Field investigation and modeling of erosion and nutrient transport and the impacts on water quality (models used: AGNPS, Erosion 3D), Modeling the water balance of a catchment and the influence of climate and land use change using distributed watershed models (e.g.,WaSimETH, SWAT, GeoSFM, WEAP), Developing integrated environmental and economic models for calculating optimal water use and allocation for decision support systems, Calculating environmental flow requirements in the context of basin water allocation strategies. Currently, Dr. Bharati is a Senior Researcher in Hydrology and Water Resources and the Head of the International Water Management Institute (IWMI)-Nepal office.

Corresponding Address: l.bharati@cgiar.org.

Pabitra Gurung, MSc, Research Officer, International Water Management Institute, IWMI-Nepal. Mr. Gurung has over six years working experience in the field of water resources. He has a Bachelor degree in civil engineering from Tribhuvan University, Nepal and a Master Degree in Water Resources Engineering degree from KatholiekeUniversiteit Leuven, Belgium. He has worked in projects in Nepal, India and Belgium. His key area of interest and expertise are in: hydrological analysis and modeling, crop water modeling, hydraulic design and climate change impact studies on water resources. Corresponding address: P.Gurung@CGIAR.ORG

Priyantha Jayakody was a Research Officer based at the headquarters of IWMI in Colombo, Sri Lanka. He is a hydrological modeler and currently persuing his $\mathrm{PhD}$ at Mississippi State University, USA. He has many years experience on water resource management, agriculture crop production and watershed modeling.

\section{References}

Arnold, J.G., R. Srinivasan, R.S. Muttiah and J.R. Williams, 1998. 'Large area hydrologic modeling and assessment', Part I: Model development, Journal of the American Water Resources Association 34(1): 73-89.

USGS, 1993.The Global Land Cover Characteristics (GLCC) database: the National Oceanic and Space Administration (NOAA) Advanced Very High Resolution Radiometer (AVHRR), daily data from April 1992 to March 1993.The U.S. Geological Survey's (USGS) National Center for Earth Resources Observation and Science (EROS), the University of Nebraska-Lincoln (UNL) and the Joint Research Centre of the European Commission. Available at:http://geoserver.isciences.com

FAO, 1995.Geospatial Information FAO Core Datasets: Digital Soil Map of the World, Soil and Soil Resources. Food and Agriculture Organization of the United Nations. Available at: http://www.fao.org/

IPCC, 2007, Climate Change 2007: Impacts, Adaptation and Vulnerability, Contribution of Working Group II to the Fourth Assessment Report of the Intergovernmental Panel on Climate Change, Cambridge, UK: Cambridge University Press.

Jones, P.G., Thornton, P.K., Diaz, W., Wilkens, P.W., and Jones, A.L., 2002. MarkSim - A Computer Tool That Generates Simulated Weather Data for Crop Modeling and Risk Assessment, Version 1.

Srinivasan, R., T.S. Ramanarayanan, J.G. Arnold and S.T. Bednarz, 1998, 'Large area hydrologic modeling and assessment', Part II: Model application, Journal of the American Water Resources Association 34(1): 91-101. 